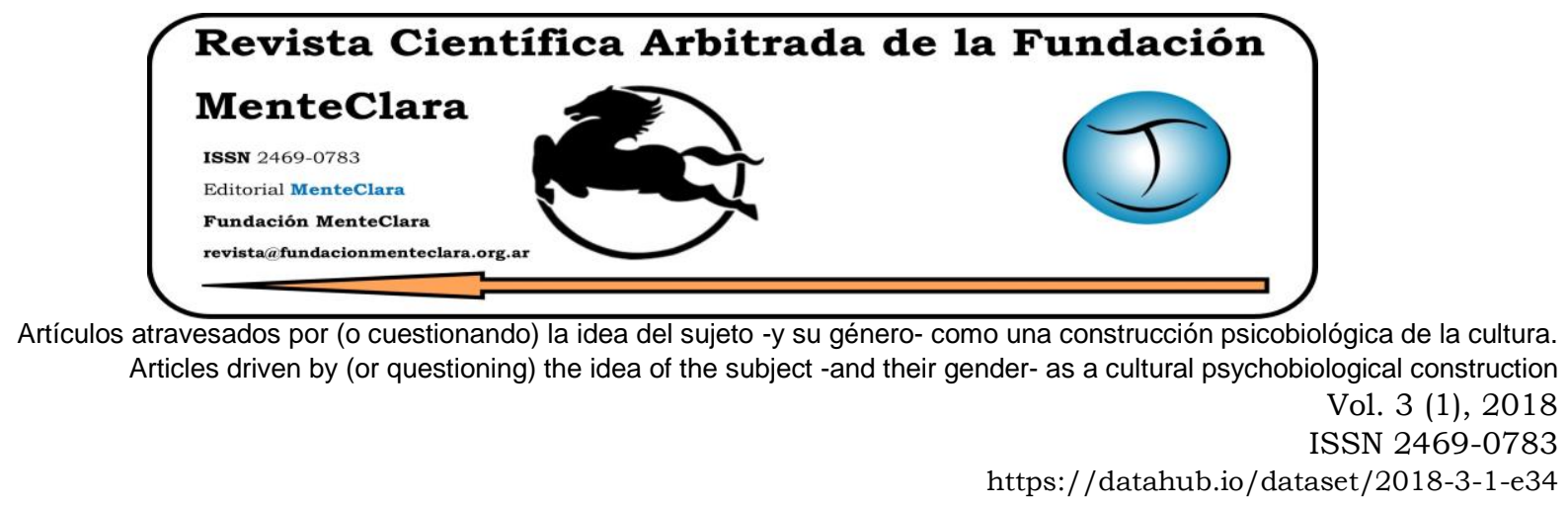

\title{
FROM CULTURAL REVOLUTION TO CULTURAL EVOLUTION
}

\author{
DE LA REVOLUCIÓN CULTURAL A LA EVOLUCIÓN CULTURAL
}

Ratan Lal Basu rlbasu@rediffmail.com

Presidency College, Calcutta \& University of Calcutta, India.

Cómo citar este artículo / Citation: Basu R. L. (2018). "From Cultural Revolution to Cultural Evolution". Revista Científica Arbitrada de la Fundación MenteClara, 3(1), 7-28. DOI: $10.32351 /$ rca.v3.1.37

Copyright: () 2018 RCAFMC. Este artículo de acceso abierto es distribuido bajo los términos de la licencia Creative Commons Attribution-Non Commercial (by-cn) Spain 3.0. Recibido: 05/11/2017. Aceptado: 05/02/2018 Publicación online: $30 / 04 / 2018$

Conflicto de intereses: Ninguno que declarar.

\begin{abstract}
In this article we look upon the concept of the Cultural Revolution from an unconventional perspective and emphasize that so far as the basic concept is concerned, Cultural Revolution has special relevance for the modern society and it may be conceived as a collective endeavour to ensure uplift of human mind and psychic modes as a whole. Here we endeavour to highlight the correspondence of the concept of the Cultural Revolution to two almost similar ways to go into the depth of the causes of maladies afflicting human society from time immemorial.

The first comparison is made with the views of the moral philosopher and economist Adam Smith who divides human sentiments into two major categories, viz. nobler elements and baser elements and attributes all maladies of human society to the later group of sentiments. The second view corresponds to the ancient Indian Sankhya Philosophy, which classifies human modes of living into three categories, viz. tamasika, rajasika and satvika, and holds the latter two modes responsible for all maladies that afflict human living.
\end{abstract}


For removal, of, maladies from human society, Smith calls for replacement of the baser human sentiments by nobler sentiments, and to this end, according to Sankhya view indicates, the initiation of a process of transition from tamasika and rajasika modes to satvika mode. A deeper look would reveal the fact that both the Smithian and Snkhya views are, in essence, the same - baser sentiments of Smith comparable to tamasika and rajasika modes, and nobler sentiments to satvika mode. However, neither Smith nor Sankhya philosophy provide any guidelines for efficacious transition of human psyche to the desired end. In this context, the concept of the Cultural Revolution becomes relevant. The concept, interpreted from a radically different standpoint from Maoist interpretation, and therefore conceived as an evolutionary process rather than a destructive revolution, may enable us to device a viable transitional process of human values and psychic from both the Smithian and the Sankhya standpoints.

\section{Resumen}

En este artículo consideramos el concepto de la Revolución Cultural desde una perspectiva no convencional y enfatizamos que, en lo que respecta al concepto básico, la Revolución Cultural tiene especial relevancia para la sociedad moderna y puede concebirse como un esfuerzo colectivo para asegurar la elevación de la mente humana y las modalidades psíquicas como un todo. Nos esforzamos por resaltar la correspondencia del concepto de la Revolución Cultural con dos formas casi similares de profundización en las causas de las enfermedades que aquejan a la sociedad humana desde tiempos inmemoriales.

La primera comparación se hace con los puntos de vista del filósofo moral y economista Adam Smith, que divide los sentimientos humanos en dos categorías principales, a saber: elementos más nobles y elementos más básicos y atribuye todas las enfermedades de la sociedad humana al último grupo de sentimientos. La segunda posición corresponde a la antigua filosofia india sankhya, que clasifica los modos de vida humanos en tres categorias: tamasika, rajasika y satvika, y mantiene los últimos dos modos responsables de todas las enfermedades que afligen la vida humana. Para eliminar las enfermedades de la sociedad humana, Smith establece el reemplazo de los sentimientos humanos más básicos por sentimientos más nobles, y para este fin, según la visión sankhya, se indica el inicio de un proceso de transición de los 
modos tamasika y rajasika al modo satvika. Una mirada más profunda revelaría el hecho de que tanto los puntos de vista de Smith y de la filosofia sankhya son, en esencia, los mismos: sentimientos más básicos de Smith comparables a los modos tamasika y rajasika, y sentimientos más nobles al modo satvika. Sin embargo, ni la filosofia de Smith ni la sankhya proporcionan ninguna guía para la transición eficaz de la psiquis humana al fin deseado. En este contexto el concepto de Revolución Cultural se vuelve relevante. El concepto, interpretado desde un punto de vista radicalmente diferente de la interpretación maoísta, y, por lo tanto, concebido como un proceso evolutivo en lugar de una revolución destructiva, puede permitirnos diseñar un proceso viable de transición de valores humanos y psíquicos desde los puntos de vista de Smith y la filosofia sankhya.

\section{Palabras Claves/ Keywords}

Mao; Adam Smith; socialtransition; culturalrevolution; culturalevolution; sankhya; tantra; science; education; transición social; revolucion cultural; evolución cultural; ciencia; educación 


\section{Introduction}

The Cultural Revolution in the Peoples Republic of China -PRC- (19661977) is now a matter of history and has been recorder as a horrifying decade-long turmoil that had wrought havoc on PRC as a whole. In retrospect criticisms have also been leveled against the theoretical premises of the Cultural Revolution and many critics have gone so far as to dub it as a Maoist Fantasy.

This article, however, looks upon the concept of the Cultural Revolution from an unconventional perspective and emphasizes that so far as the basic concept is concerned, Cultural Revolution has special relevance for the modern society and it may be conceived as a collective endeavour to ensure uplift of human mind and psychic modes as a whole. In fact, in this article, our purpose is to relate the concept of the Cultural Revolution to two almost similar ways to go into the depth of the causes of maladies afflicting human society from time immemorial. Both of them, although presented in two apparently different formats, are in essence the same as of them endeavour to highlight human psyche as the root cause of all maladies afflicting human society. One such view has been put forward by the moral philosopher and economist Adam Smith who divides human sentiments into two major categories, viz. nobler elements and baser elements and attributes all maladies of human society to the later group of sentiments. The second view corresponds to the ancient Indian Sankhya Philosophy [1] according to which human modes of living are of three categories, viz. tamasika, rajasika and satvika. Human maladies according to Sankhya aphorisms arise from tamasika and rajasika modes of living. For long term solution of basic problems of human society on the basis of Smithian view, the baser human sentiments are to be replaced by nobler sentiments; and according to Sankhya view, sustainable removal of maladies calls for transition of 
tamasika and rajasika modes to satvika mode. In fact, both the approaches come down to the same endeavour. Smithian baser sentiments are nothing but manifestations of tamasika and rajasika modes. Unfortunately, neither Smith nor Sankhya philosophy has provided any efficacious guidelines for efficacious transition of human psyche required by them for uplift of human society. Here comes the relevance of the concept of the Cultural Revolution. The concept, interpreted from a radically different standpoint from Marxian or Maoist interpretation, may provide us the viable transition of human values and psychic from both the Smithian and the Sankhya standpoints.

Before venturing into this endeavour towards reinterpretation and revaluation of the concept of the Cultural Revolution in order to resolve the basic problems of human society through psychic uplift of human society, let us first have a glimpse of the turbulent Maoist Cultural Revolution, its theoretical and ideological premises, and its horrible impacts on the socio-political and economic framework of the PRC.

\section{Mao's Cultural Revolution}

Marx failed to realize that causes of poverty, inequality, exploitation and similar maladies do not lie in private property, family relations, the state or any other visible phenomenon, but it lies deep in human nature, in the unethical elements like greed, pride, jealousy. So, eradication of the maladies, if at all possible, is to be accomplished by some process that would reduce the prevalence of these basic vices in human mind. Apparently it appears that through the Cultural Revolution, Mao wanted to fight against these basic vices of human mind that are likely to be responsible for the maladies in the material world. However, many factors make it dubious whether Mao's Cultural Revolution targeted at 
eradication of the primordial vices inherent in human mind. Let us have a deeper look into Mao's Cultural Revolution and examine what exactly had its real objective been.

The following developments prompted Mao to hastily resort to the Cultural Revolution:

Increase in power in the Communist Party of the pragmatic group. This group was strongly opposed to the Maoist radicals like Jiang Qing, Mao's wife; Lin Biao, the Defence Minister; Chen Boda; Kang Sheng and Wang Donxing.

The liberal leaders -like Deng Xiaopinging, Liu Shaoqui, and the premier Zhou Enlai-. Opposing Maoist Radical Views had realized from China's experience with socialism in course of a decade -especially the horrible outcomes of the so called "Great Leap Forward"- that Mao's experiments would be disastrous for China's economic development and there was no way out but to undertake drastic reforms and adoption of the capitalistic or bourgeois path of economic development.

\section{The Great Leap Forward}

Mao wanted to adopt radical policies to jump directly from a semifeudal economy to a socialist economy in a short span of time.

The Second Five Year Plan (1958-63) was chosen as the starting point of that 'great leap forward'. Drastic economic policies in line with Maoist Principles and aggressive foreign policy were adopted as ingredients of this radical step. But the disastrous consequences were felt as early as 1959. Soviet Union, which was declared by Mao as revisionist, withdrew economic and technical support, enmity developed with India and the USA, production in agriculture and industry fell drastically. 
These combined with natural disasters resulted in death of nearly 20 million people during 1959-60. By 1961 the Maoist policy was abandoned and moderates like Liu Shaoqi, Deng Xiaoping and Chou Enlai reverted Maoist approach. Mao was held responsible for the disaster and he resigned from the position of head of the state (although retained the position of Party chairmanship). The three moderates had restricted Mao's power but by the ordinary Chinese people he was still seen as the leader of the revolution and the Father of Nation. He wanted to use his mass popularity resurrect his authority at the expense of the moderates. So he planned to launch the so-called Cultural Revolution -CR-. [2]

\section{The Cultural Revolution}

The basic goal of the Cultural Revolution, Mao declared, would be the removal of the Capitalistic roaders -the liberals- from power in the communist party and restore the Marxist path of class struggle. The following extracts from Mao's directives are evidence of this approach of the Cultural Revolution.

1. "The old Social Democrats in the past decades, and modern revisionists in the past dozen years or so have formed a group of anticommunist, anti-people, and counter-revolutionary elements against whom we are waging a life-and-death struggle. There is no equality between us and them. Therefore the fight against them is a fight for our preservation and their extinction. The relationship between us and them can never be one of equality; it is a relationship of one class oppressing another, i.e. proletarian dictatorship over the bourgeoisie. The day when the people are happy will be the day when the counter-revolutionaries begin their misery". (Mao, 2004, dt. 10-6-68) 
2. "The basic contradiction the great proletarian Cultural Revolution is trying to resolve is the one between the proletariat and the bourgeoisie, between the proletarian and bourgeois roads. The main point of the movement is to struggle against the capitalist roaders in authority in the party". (Ibid. dt. 24-9-1966)

3. "The basic problem of a revolution is the problem of political power. The possession of political power means the possession of everything, the loss of it means the loss of everything". (Ibid. dt. 13-8-67)

To fight the opponents Mao wanted to take help of the students and the masses who could be easily moved by emotional and idealistic preaching. Red Guards formed mostly of young students were directed to attack Mao's opponents.

1. "The revolutionary red guards and revolutionary student organizations must form a grand alliance. As long as they are revolutionary mass organizations, they must form a great alliance according to revolutionary principles." (Ibid. dt. 1-10-67)

Mao also realized that without control over the military force it would not be possible to combat and corner the opponents.

To win the support of the military force, especially the Peoples Liberation Army -PLA- he forged an alliance with Lin Biao, the Defence Minister with the assurance that he would be the successor of Mao. Mao put forward the following guidelines for Lin Biao and the Army in a letter to Lin Biao:

"You must dispatch troops to support the broad left-wing revolutionary masses. Later on, whenever true revolutionaries need support from the PLA, you should do likewise. The so called 'non-interference' is untrue. [The $P L A]$ has been involved for some time. I think on this matter you should issue new orders; the old ones should be cancelled." (Ibid. dt. 23-1-67) 
Now as regards the first and foremost task of the pro-Cultural Revolution student-mass-army alliance, Mao issued the directive:

"Bombard The Headquarters - My First Big-Character Poster" (Ibid. dt. $5-8-66)$

So it becomes clear that in contrast to the common belief, Mao's Cultural Revolution had nothing to do with moralistic development of human society. It was simply an endeavour to restore and strengthen the erroneous path of class struggle, which ultimately degenerated into a struggle for power within the Communist Party of China.

\section{Consequences}

The consequences of the Cultural Revolution was simply devastating chaos, anarchy, civil war, arson, looting, wanton damage of property and productive resources, killings, in brief, the Cultural Revolution left China in a condition experienced by a land gripped under a horrible cyclone.

In course of the turbulent incidents, there were shuffling and reshuffling of power from one leader to another. At the beginning, it turned out to be a power struggle between two radical groups led respectively by Lin Biao and Jiang Qing. With the supremacy of the latter group, Chen was arrested and disappeared and Lin killed in a plane crash while fleeing China in 1971.

But then the wind turned, now against the remaining radicals led by Jiang Qing. Mao died and then Jang Qing, the last supporter of the CR, was arrested in 1976. CR came to its end leaving China in shambles. (Barnouin and Yuchanggen 1993, Chen 1975, Domes 1973, Joseph et. al. (eds.) 1991, Lee 1978, Tang 1986). 


\section{Chronology}

May 1966: Concept of Cultural Revolution -CR- in Communist Party newspaper.

August 1966: Mao officially launched CR. Formed the Red Guards to combat his opponents in the Communist Party

October 1966: At a mass meeting in Tiananmen Square Mao called for the Red Guards to destroy the four olds: old ideas, old behaviour.

Fall 1966: Mao closed schools and on the basis of his directives the Red Guards challenged and attacked -- verbally and physically -- party leaders \& government officials, intellectuals and people in positions of power and influence. Mao left Beijing, leaving Liu Shaoqi and other top leaders to handle the social turmoil. Mao later returned to Beijing after a much publicized swim in the Chang Jiang -Yangtze River-. Mao deemed Liu Shaoqi a counter revolutionary. Later Liu's wife was publicly humiliated at a mass meeting. She and Liu were arrested and imprisoned. Liu was beaten and tortured to death.

January 1967: Red Guards overthrew the provincial party committee officials and replaced them with radicals.

February 1967: Party officials called for an end to the CR but Mao continued to support it.

July 1967: Red Guards attacked the political leadership of the city of Wuhan and a full-fledged civil war ensued. Zhou Enlai personally interceded to resolve the crisis by restraining the Red Guards.

Summer 1967: Fight among rival factions of Red Guards ensued and Mao ultimately ordered Lin Biao to use the Army to bring order to the Red Guard movement. 
1968: The disorders caused by the CR resulted in $12 \%$ decline in industrial production in 1968 compared to 1966. The Army took control of government-offices, schools and factories. Millions of young people were sent to the countryside to 'learn from the peasants'.

April 1969: Border clashes with the USSR -- declaration of Martial Law by Lin Biao who was declared the official successor of Mao. Mao opted for open talks with the USA to combat the Soviet threat.

1970-71: Jiang Qin's group started opposing Lin as successor of Mao.

August 1971: Chen Boda, a supporter of Lin was arrested and soon he disappeared.

September 1971: Lin Biao was killed in plane crash in Mongolia attempting to flee China - accused of plotting to kidnap and kill Mao and take control of China himself.

Late 1971 - mid 1973: Mao had a stroke and Chou, cancer.

February 1972: Richard Nixon visited China. The Shanghai Communiqué defining China-US friendship issued.

Early 1973: Deng rehabilitated.

Mid 1973 - mid 1974: Jiang Qing group dominant in government.

July 1974: Mao shifts support to Zhou and Deng.

Fall 1974: Mao shifted back support to Qing -- Deng formally removed from power.

January 1976: Zhou died.

February 1976; Hua Guofeng appointed acting premier.

September 1976: Mao died. Hua made party Chairman.

October 1976: Armed forces arrest Qing and her group - the so called 'gang of four'. 
July 1977: Cultural Revolution ended and Deng emerged as the most paramount leader of China.

Later the 'gang of four' was tried and Qing was imprisoned in 1981. She committed suicide in prison in 1991.

\section{Adam Smith and Human Dilemma}

According to Smith's philosophical masterpiece, The Theory of Moral Sentiments', the basic sentiments of man can be broadly divided into two opposite categories: self interest and fellow feeling. All the major sentiments belonging to either of these two categories are assumed by Smith to be endowed to man by Nature.

"The great division of our affections is into the selfish and the benevolent." (Smith 1759, VII.II.4).

All human ethics belong to the second category of the Smithian sentiments, viz. 'fellow feeling'. Material progress is brought about mainly by the motive of improving one's own condition -a motive belonging to the 'self interest' category- and in its full manifestation it becomes the dominant sentiment.

"It is this which first prompted them to cultivate the ground, to build houses, to found cities and commonwealths, and to invent and improve all the sciences and arts which ennoble and embellish human life, which have entirely changed the whole face of the globe, have turned the rude forests of nature into agreeable and fertile plains, and made the trackless and barren ocean a new fund of subsistence and the great highroad of communication to the different nations of the earth" (Ibid. IV.I.10) but ".... is the cause of all the tumult and bustle, all the rapine and injustice which avarice and ambition have introduced into this world" (Ibid. I.III.23). 
Capitalistic system opens up endless opportunities for material advancement of traders and industrialists, and in their reckless drive towards achieving higher and higher gains, all ethical sentiments, fellow feeling and human values are bound to be swept away.

The paradox here is that materialistic progress is not possible without the baser human sentiments of self interest of greed and desire for power but these are also responsible for all maladies associated with materialistic progress. The question is how to minimize the adverse impacts of the self-interest based materialistic progress. This could be done through moderating self interest through infusion of ethics and nobler sentiments in human mind. But the most serious hurdle on the path of this objective may be termed the Smithian Dilemma.

\section{The Smithian Dilemma}

In brief the Smithian Dilemma is the psyche of most of the people to admire the rich and powerful even if these persons have achieved their power and wealth through unscrupulous means. On the other hand, an honest and virtuous person who is poor and who lacks power in society is neglected, even looked down upon by the common people.

Going deep into basic human psychology, Adam Smith opines that whatever be their own positions, most of the people praise and worship the successful and rich people, irrespective of whether their successes have been achieved through ethical or unethical means. Moreover, most of the people cherish in their subconscious, the hidden desire to achieve opulence and fame so as to get the praise and approbation of all and sundry.

"This disposition to admire, and almost to worship, the rich and the powerful, and to despise, or, at least, to neglect persons of poor and mean 
condition, though necessary both to establish and to maintain the distinction of ranks and the order of society, is, at the same time, the great and most universal cause of the corruption of our moral sentiments. That wealth and greatness are often regarded with the respect and admiration which are due only to wisdom and virtue; and that the contempt, of which vice and folly are the only proper objects, is often most unjustly bestowed upon poverty and weakness, has been the complaint of moralists in all ages." (Ibid. I.III.28)

"We desire both to be respectable and to be respected. We dread both to be contemptible and to be condemned. But, upon coming into the world, we soon find that wisdom and virtue are by no means the sole objects of respect; nor vice and folly, of contempt. We frequently see the respectful attentions of the world more strongly directed towards the rich and the great, than towards the wise and the virtuous." (Ibid. I.III.29)

"In equal degrees of merit there is scarce any man who does not respect more the rich and the great, than the poor and the humble. With most men the presumption and vanity of the former are much more admired, than the real and solid merit of the latter." (Ibid. I.III.31)

\section{Sankhya Solution}

According to Sankhya Philosophy, human consciousness is a part of material manifestation of Nature and it is the combination of three modes viz. satva, rajas and tamas, endowed by Nature. All these basic modes combine in different degrees to assign different characteristics to different individuals. If isolated in the abstract, unmixed satva pertains to goodness and virtue, rajas to passion and insatiable desire and tamas to darkness of mind, obsession and inertia. All our mental and intellectual 
faculties originate from these three basic modes. (Ballantyne 1885: I.61, I.125-27, I.141, II.27).

The creator is omnipresent but nirguna -having no attribute-.

But human beings are saguna -having specific attributes- which are of three categories, viz. (I) tamasika-dominated by 'tamas' mode-; rajasika-dominated by 'rajas' mode-; and (III) satvika-dominated by 'satva' mode-. Satvika people are characterized by nobler qualities -like abstinence, self-sacrifice, love, philanthropy, mercy, self-confidence, diligence, and composure- whereas rajasika and tamasika people possess various combinations of baser qualities -like greed, envy, hatred, anger, selfishness, lust, idleness, cruelty, and pride-.

Now let us take up another concept of Hindu Philosophy, viz. the concept of ripu. In general ripu means enemy. These ripus in Hindu Philosophy are excesses of some basic instincts or reflexes of human mind or intellect. These basic instincts are necessary for our material existence. So as such they are not enemies. But for beneficial effects they must be balanced and kept under our control. If they are in excess, they become our enemies or ripus and result in disastrous effects both for us and for the human society. The western scholars often mistakenly translate ripu as sin. But ripus are not sins, rather reasons for sins or vices. There are six ripus, viz. Kama -desire for material pleasure/sexual desire / lust-, krodha -anger-, lobha -greed-, moha -infatuation / attachment /obsession-, mada -pride / vanity / arrogance-, matsarya -envy-.

"Shree Devi said, "The Yoga does not exist in the Heavens; nor does it exist on earth or in the nether regions-Patala-. Those who are skilled in the Yogas say that the realisation of the identity between the Jivatma and the Paramatma is Yoga O Sinless One! The enemies to this Yoga are six; 
and they are lust, anger, greed, ignorance, vanity and jealousy. The Yogis attain the Yoga when they become able to destroy these six enemies by practicing the accompaniments to Yoga." Vijnanananda (1921-22)

The basic instincts, pertaining to the ripus, can be used for good or bad and by themselves they are neutral. Our endeavour ought to be not to eliminate them but to control them and become their masters. Sexual desire is normal and good, but obsessing with sex and using it to harm is not. Anger is also a necessary element that makes us human -- without it we cannot have respectability. Greed is a form of desire -- it can be an insatiable foolish desire or positive desire that can be used as an incentive for progress. Likewise, vanity and pride are necessary for self respect and envy can foster healthy competition. If the basic instincts are kept under control, they are always beneficial, but if they get the better of us, they turn into enemies and ruin us in the short or long run.

Under satva mode, ripus are fully controlled and turn out benign - they reside in such a person in perfect harmony with ethical living. On the other hand, under rajas and tamas modes, ripus become dominant and take control of the persons involved and so, become disastrous both for the individuals involved and for the society as a whole.

According to the above analysis, advancement of human society and removal of maladies call for transition from the tamas and rajas states to satva state. However, no ancient Hindu text provides any specific guidelines in order to initiate this process of transition. Only the Kulanava Tantra -a text from the seventh century- proposes the Kaula path as a path of self-realization and a set of techniques for men, as a whole and regardless of caste, to grow morally to achieve the same human dignity regardless of their birth circumstances. This text proposes to teach reading and writing even to pariahs, and once within the clan, a pariah who had reached a higher education level and had sufficient 
merits, was above a newly initiated Brahmana. Within the clan, meritocracy ruled (Gómez, 2017). The clan Kaula followers and the Vajrayana -Tantric Buddhism- practitioners were exterminated in India upon the end of the Sailendras empire, which sponsored and protected them between the 8 th and 13th centuries. Their texts and their liberating teachings, destroyed, some of them taking refuge in Central and Maritime Asia (Acri, 2017).

Mao most surely has referred to this source when he defined himself as a tantric adept (Chhaya, 2007) and asked the Dalai Lama why, being he himself a tantric practitioner, had not headed a movement to free the peasants from oppression and ignorance (Gómez, 2013).

Here comes the relevance of the concept of the Cultural Revolution.

\section{Conclusion}

\section{Cultural Revolution to Cultural Evolution - the Wayout}

If we analyze with deep insight, both Sankhya and Smithian causes of maladies of human society would come down to the same thing in essence - causes of maladies in human society lie deeply in basic vices of human mind, viz. greed, pride, jealousy, hatred and the way out lies in infusing in human society as a whole nobler human values like love, sacrifice, sympathy, fellow feeling, philanthropy, and by doing so, to gradually minimize the adverse impacts of the basic vices. It is unrealistic to think that all the basic vices could be eradicated or rooted out completely. However, a balance could be struck between the baser forces and nobler forces.

Now the question arises as to the social processes that are likely to accomplish this highly desirable but extremely intricate task. Neither 
Sankhya nor Adam Smith provides any viable and effective means to this end.

Here comes the relevance of the Cultural Revolution, which in essence, signifies a process, that through collective social efforts, is likely to infuse nobler and humanitarian values in human society as a whole. The problem with Maoist, and for that matter basic Marxian approach to the Cultural Revolution, was that it mixed up this social process with class struggle and violent means. This is the basic reason for failure of the Cultural Revolution in China and the consequent destruction of property, loss of life and above all chaos and confusion leading Chinese economy, polity and society as a whole to doldrums.

We may, however, dissociate the concept of the Cultural Revolution from the Marxian and Maoist fantasies of class struggle and the destructive violent means, and get down to the broad connotation of the concept, viz. a social process of purification of negative psychic forces leading to maladies of human society. The term 'Revolution' may, however, appear to signify a violent means of radical change in a short span of time. So we may better use the term Cultural Evolution -C. E. to avoid confusion. So Cultural Evolution may be conceived as a long term evolutionary process of modification of human values and mental attitude.

The following three questions come up in connection with this concept of Cultural Evolution:

1. Which specific manifestations of basic vices to be targeted to start with.

2. How to accomplish this.

3. Principal agencies to play the crucial role in this regard.

Let us elaborate the basic question as mentioned above. 
Q1. Which Specific Manifestations of Basic Vices to Be Targeted

The major manifestations of basic vices to be targeted to start with are:

1. Religious and Other Superstitions

2. Unnecessary and Burdensome Religious Rites

3. Blind Devotion to Religious Priests and Gurus

4. Blind Devotion to Political Parties and Political Leaders

5. Blind Devotion to All Categories of Celebrities

6. Division of Society on the Basis of Caste, Creed, Mother Tongue, and Religion and Reservations, Untouchability, Discrimination on the basis of them

7. Tamasika Attitude and Activities of Political Parties and Mass Media Q2: How to Accomplish the Above Tasks

The immediate measures to be undertaken in order to initiate the process of the Cultural Evolution are the following:

A. Rapid Industrialization \& Technological Advancement -rajasika modes of production- in all spheres of the economy in order to completely eradicate all vestiges of pre-capitalistic -tamasika- modes of production.

B. Complete removal of illiteracy

C. Spread of Moral \& Scientific Education in order to inculcate scientific and ethical world outlook.

Q3: Principal Agencies

Enlightened Intellectuals, NGOs, Government, Mass Media, Educational Institutions 
The Most Obstinate Obstacle on the path of initiating Cultural Evolution is likely to be the basic human psyche discussed in section III as the Smithian Dilemma.

So a major task at the beginning of initiation of the Cultural Evolution would be to confront the serious obstacle pertaining to the Smithian Dilemma. This is one of the most serious hurdles and methods are to be devised to tackle it. Considering the seriousness of this problem, it is necessary to discuss the issue in detail in a separate and full-fledged article. 


\section{Notes}

1. There are six Vedic philosophies: Nyaya of Gautama, Mimamsa of Jaimini, Vaisheshika of Kanada, Sankhya of Kapila and Yoga of Patanjala.

2. See http://www.historylearningsite.co.uk/great_leap_forward.htm

\section{References}

Acri, A. (2017). "Viajando por los "Caminos del sur": El budismo esotérico en el Asia marítima, siglos VII-XIII d. C.". Revista Científica Arbitrada de la Fundación MenteClara, 2(2), 6-62. http:/ / fundacionmenteclara.org.ar/revista/index.php/RCA/article/view/28

Ballantyne, James R. (translator) (2004), Sankhya Aphorisms of Kapila (Sanskrit Text with English Translation), Revised New Edition, Delhi, India Parimal Publications.

Barnouin, Barbara and Yu Changgen (1993), Ten Years of Turbulence, London, Kegan Paul International.

Chen, Jac (1975), Inside the Cultural Revolution, New York, MacMillan.

Chhaya, M. (2007) Dalai Lama. Man, Monk, Mystic, Doubleday, 2007

Domes, Jurgen (1973), The Internal Politics of China 1949-72, New York, Praeger.

Gómez, O. R. (2013). "El tantrismo dentro de la Compañía de Jesús - del Tíbet al Vaticano hoy" Buenos Aires, Argentina: Ediciones Menteclara.

http://tantra.org.ar/biblioteca/index.php/Biblioteca/article/view/4/5

Gómez, O. R. (2017). "Análisis crítico del Kularnava Tantra -Parte 1- Un prólogo viciado de sexualidad reprimida". Revista Científica Arbitrada de la Fundación MenteClara, 2(1), 114-141. http://fundacionmenteclara.org.ar/revista/index.php/RCA/article/view/26

Joseph, William et al. (eds.) (1991), New Perspectives on the Cultural Revolution, Cambridge, MA, Harvard University Press.

Lee, Hongyong (1978), The Politics of the Chinese Cultural Revolution, Berkeley, CA, University of California Press.

Mao Tse-tung (2004), "Directives Regarding Cultural Revolution 1966-69”, Selected Works Vol. IX, Secunderabad, Kranti publications.

https://www.marxists.org/reference/archive/mao/selected-works/volume9/mswv9_84.htm 
Smith, Adam (1759), The Theory of Moral Sentiments. London, A. Millar, Sixth edition, 1790 .

Tang, Tsou (1986), The Cultural Revolution and post-Mao reforms: a historical perspective, Chicago. University of Chicago Press.

Telang, Kashinath Trimbak (translator) (1882), The Bhagavad Gita, The Sacred Books of the East, Vol.8, Oxford Clarendon Press.

Vijnanananda, Swami (translator) (1921-22), Srîmad Devi Bhagavatam (Devi Purana), (Book-7, Chapter-35, Slokas-2-3), Scanned, and proofed by Sahaji, 2004-5.

http://upload.vedpuran.net/Uploads/68655SrimadDeviPurana.pdf 